\title{
The concept "salvation" in the Church of Scientology
}

\author{
S P Pretorius \\ Registration Administration \\ University of South Africa
}

\begin{abstract}
In one of its publications the Church of Scientology (COSI), a wellestablished religious movement in South Africa, claims to be not only the fastest growing religious movement, but also to be an active force for positive change in the world. The Church of Scientology's utilization of familiar terms such as "church" and "religion" can be misleading. It can create the understanding with some that Scientology might be related to, or even be an extension of the Christian tradition. This understanding is further enhanced by their assurance to Christians that joining the church will not distance them from, but instead, strengthen their own faith. This article, however, concludes that closer investigation of the philosophy of Scientology indicates that there is a distinct difference between the salvations offered by Scientology and that of the Christian tradition.
\end{abstract}

\section{INTRODUCTION}

On 3 April 2000, the Department of Home Affairs granted 12 ministers of the Church of Scientology the right to perform marriage services. This means that the Church of Scientology is now fully recognised as a religion and as a valuable contributor in the new South Africa. It also freed the church from being labelled a cult (Anon 2000:3). The church took a positive step when the first black minister was appointed later in 2000 (Khumalo 2000:15).

The father of Scientology is L Ron Hubbard (COSI 1998a:4). In 1954 the first Church of Scientology was formed in Los Angeles by a group of his followers, and within a few years churches were planted throughout the United States of America and all over the world (COSI 1998a:524). L Ron Hubbard authored the writings (or scriptures) of the Church of Scientology. One of Hubbard's bestsellers is known as the "bible" of Scientology. It is entitled Dianetics: the modern science of mental health and is recommended to prospective members who want to acquire a basic understanding of the workings of the mind (COSI 1998a:544). The following statement shows how 
much importance is attached to dianetics: "History has become a race between Dianetics and catastrophe. Dianetics will win, if enough people are challenged in time to understand it" (COSI 2004:1).

The church boasts that it has more than 3200 churches, missions and groups in 154 countries. It offers a variety of services and programmes to the public. The aim of these services is to enrich and better the human race. The maxim of Scientology is that only the things one finds to be true are true. This is only possible when a person is capable of independent thought on the voyage of self-discovery. This voyage of self-discovery ultimately leads to salvation.

In this article, the nature of salvation offered by Scientology is examined. We also attempt to answer two questions: How is this salvation obtained? And how does it compare to Christian salvation?

In order to understand the concept of salvation in Scientology, the roots of Scientology and Scientologists' view of God, sin and the position of a human being need to be clarified.

\section{ROOTS OF SCIENTOLOGY}

Scientology has a long history of religious philosophy and practices.

Scientology dates back to $1500 \mathrm{BCE}$, when early man painted bulls and other images on walls of deep caves in Lascaux, France, because it was believed that representations of animals would bring the living animals closer to the people and in that way guarantee a successful hunt. As illustrated by this example, human beings have been trying to understand their relationship to other living things and the physical universe for countless eons (COSI 1998a:8).

Scientology shares many of its beliefs with other religions and philosophies (COSI 1998:3). The basic tenets of Scientology seem to result from a mixture of Eastern philosophies, Hubbard's personal research into a variety of disciplines and data that was uncovered from "auditing". ${ }^{1}$ The sources of Scientology include the Vedas, Buddhism, Judaism, Gnosticism, Taoism, early Greek civilization, and the teachings of Jesus, Nietzsche and Freud (Ankerberg \& Weldon 1996:524). Hubbard incorporated bits and pieces of many different philosophies and practices to create an applied religious philosophy known as Scientology, which he calls "the Western anglicised continuance of many earlier forms of wisdom" (Hubbard 1968:177). COSI explains the religion as follows:

\footnotetext{
${ }^{1}$ Auditing refers to "counselling" that is done by Scientology. Through auditing an extensive examination of the present or "past lives" of a person is done (Ankerberg \& Weldon 1996:524). The word auditing is taken from the Latin word audire which means to hear or listen (COSI 1998:684).
} 
Scientology is heir to the understanding of thinking men since the beginning of human history, that man is a spiritual being who aspires to understand and improve life. The search has been long, but answers now exist in Scientology for anyone who wishes to reach for them.

(COSI 1998a:7)

The name Scientology is a combination of the Latin word scio, which means "know", and the Greek word logos, which means "the word or outward form by which the inward thought is expressed and made known" (COSI 1998a:690).

The influence of the different philosophies on the concepts will be discussed later.

\section{SCIENTOLOGY AS RELIGION}

Scientology claims to be a religion. This is evident from the following statement: "Scientology is a religion in the most traditional sense" (COSI 1993:432). The Church of Scientology also believes that it is the fastest growing religious movement on earth (COSI 1994:3).

The origin of the word "religion" is not altogether clear. It is thought to derive from one of two combinations of Latin roots, namely, re and legio, which mean "re-reading". Another combination of Latin term, namely re a ligio, which means "reconnection" is favoured by more modern scholars. Others interpret the Latin word ligio as "ligament" (in the sense of "bind"), and therefore hold that religion means "returning to bondage". The general notion, however, is that religion indicates a "meaning seeking" system. Occasionally the word "religion" is used to designate what should be more properly described as a "religious organisation" - that is an organisation of people that supports the exercise of some religion, often taking the form of legal entity (Anon 2005:2).

Religion can be commonly defined as a set of beliefs about the supernatural, sacred, or divine, and the moral codes, practices, values and institutions associated with such beliefs (Anon 2005:1). Apart from the abovementioned broad definition of religion, there are a variety of uses for the word "religion". One of the important approaches is the "function-based approach", which defines religion as any set of beliefs and practices that has the function of addressing the fundamental questions of human identity, death and existence of the divine. This definition includes those who believe in the existence of one god, as well as those who believe in the existence of many gods. The second approach defines religion as any set of beliefs that makes 
claims that lie beyond the realm of scientific observation. This is called a "form-based approach". The third approach is to define religion as the beliefs about cause and effect. This is called the "physical evidence approach". Nonreligion is defined as any set of beliefs that admits no more causes of natural things than such as are both true and sufficient to explain their appearance. Lastly, religion is defined as formal institutions, creeds, organisations, practices and rules of conduct, of all major, institutionalised religions. This is called an "organisational approach" (Anon 2005:3).

The Church of Scientology meets the three criteria of an "ethically neutral" definition that are generally used by religious scholars to determine religiosity, namely (1) a belief in some Ultimate Reality that transcends the here and now of the secular world, (2) religious practices directed towards understanding, attaining or communing with this Ultimate Reality and (3) a community of believers that are joined in pursuing this Ultimate Reality (COSI 1998b:5). The approach of Scientology (in terms of the abovementioned approaches) seems to be functional as well as organisational.

Scientology does address the functional issues of life, death, existence and the divine, and also the importance of understanding the "self" and that which prevents the "self" from functioning optimally. Scientology offers a spiritual philosophy that emphasises the need for practices and services in order to achieve human happiness.

Scientology can be defined as a formal institution with creeds, practices, services and rules of conduct. It can be described as a centralised religion with a structured organisation with a "mother church", namely the Church of Scientology International, with its headquarters in Los Angeles. The "mother church" is responsible for the ecclesiastical supervision of the Scientology churches around the world. The rest of the structure consists of "field staff members" who provide material and introduce people to the church; "ministers", who are members who have completed the ministerial course and who deliver Scientology religious services to church members; staff members in the "Office of Special Affairs" (OSA) who deal with legal affairs; and staff members in the "Flag Service Organization" (FSO) located in Clearwater Florida, who deliver advanced spiritual training and auditing. Higher up in the structure is the "Flag Ship Service Organization". This is an advanced religious retreat that delivers the level of auditing called New OT VIII and provides specialised training to Scientologists. Another step higher is the "Sea Organization" (Sea Org). The members of Sea Org are the most dedicated Scientologists who have devoted their lives to Scientology. At the top of the structure is the board of directors (COSI 1992:556-557). 
If the works of Scientology are analysed, it is clear that the movement has religious characteristics. Scientology is not a religion in the sense that it engages in formal, outward acts and repetitions. It rather relates to the individual in his or her life and endeavours to free the individual by the truth it provides.

\section{SCIENTOLOGY AS "CHURCH"}

Scientology refers to itself as a "church". The word "church" is a broad term and comes from the Greek word kyrios, meaning "lord", and the IndoEuropean base kewe, meaning "to be strong" (COSI 1998a:525). In the Greek New Testament the word used to describe church is "ekklèsia", which means "a congregation" (Anon 1977:381) or a "political gathering" (Oosthuizen 1977:4). The term "ekklèsia" cannot be said to apply only to "the called ones" in the New Testament. The term was in use before the Christian era for "a gathering of members of a clearly defined group". In the Greek it was generally used to refer to a sosiopolitical entity based on citizenship of a citystate (Louw \& Nida 1993:126).

Scientologists base their claim to be a "church" on the fact that the word "church" does not exclusively belong to the Christian tradition. In modern terms people may speak of the Buddhist or Muslim church. A church simply means a congregation of people who participate in common religious activities (COSI 1998a:525). Scientology therefore uses the wider term "church" and do not profess to be a "Christian church".

\section{IMPORTANT CONCEPTS IN SCIENTOLOGY}

How Scientology views God, mankind, sin, the relationship between God and mankind, and life will determine the nature of salvation the church offers.

\subsection{The concept of God}

In Scientology the concept of God is expressed as the eighth dynamic - the urge towards existence as infinity. It embraces the allness of all. God is also called the Supreme Being, All Theta or Author of the Universe (COSI 1998a:530). No clear dogma concerning God is imposed on its members. The Church of Scientology never asks its members to believe anything on the basis of faith. As members' spiritual awareness increases through participation in Scientology, they can reach their own conclusions about the nature of God and what lies in store for them after their present lifetime (COSI 1998a:530). 
The concept of God in Scientology would appear to be partly panentheistic and possibly polytheistic. Scientology's reference to God as the eighth dynamic and infinity that embraces the allness of all indicates at least some belief in panentheism. Scientology seems to grant thetans ${ }^{2}$ the status of an ontologically real, independent existence. It seems that a thetan is also viewed as an eternal being or a "god with infinite creative potential". In this case a polytheistic classification is appropriate (Ankerberg \& Weldon 1996:525).

Scientology has relatively few references to Jesus Christ. Jesus Christ is not viewed as the only incarnation of God and divine saviour of the world. The salvation brought about by the death of Christ is viewed as one possible way of salvation - the salvation to heaven (COSI 1992:545). Christ's death is rather viewed as symbolic of the triumph of the spirit over the material body and has brought about a new awareness of man's true nature (COSI 1998a:13). Christ's divine nature is denied. He is viewed as an ordinary person, as is evident from the following statement: "Neither Lord Buddha nor Jesus Christ were OTs (Operating Thetans - enlightened as to their true spiritual nature) according to the evidence. They were just a shade above

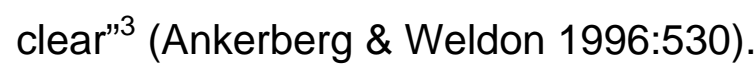

Scientology provides no clear classification of God. The nature of the relationship between God and mankind is also vague and left to be determined by each individual according to his or her own experience. There is no indication that this relationship is a personal relationship, as in the case of Christianity.

\subsection{The concept of man}

Contrary to the Church of Scientology's limited reference to God, its descriptions and references to man abounds. At the core of its concept of man lies the belief that man is inherently good, highly ethical and not evil (COSI 1998a:20).

Scientology views people as spiritual beings that have minds and bodies. The spiritual essence of man is defined differently. Terms such as "spirit" and "soul" had been used to signify countless things over the centuries

\footnotetext{
${ }^{2}$ The term "thetan" is used by Scientology to refer to the soul or an immortal spiritual being (COSI 1998:690).

${ }^{3} \mathrm{~A}$ "clear" is a person who no longer has his/her own reactive mind (which is the storeroom of all negative experiences). The term "clear" therefore means that a person's reactive mind has been cleared of all negative pictures and experiences (COSI 1998:685).
} 
and as a result, Hubbard coined a new word. He used the Greek letter theta to represent the transcendent "life force" in all living things. By adding the " $n$ " to theta the word thetan was formed to describe the individual unit of "life force" (COSI 1998b:18). Although a thetan is basically good and highly ethical, it is also simply ignorant of its own perfection. Scientology does not deny the fall of man, but argues that man has fallen into matter and not sin. Man's fall is therefore not a moral matter, as is believed in other religions.

The fall of man is described in the following manner: The life force that animates all living things is separate from, but acts upon, the physical universe, which consists of matter, energy, space and time (MEST). However, in the relationship between MEST and the thetan, MEST tends to encumber the thetan and causes it to act contrary to its true spiritual nature. This is called "spiritual entrapment by MEST" or "fall from perfection". This fall from perfection is not the result of Satan or man's natural evil impulses, but is caused by the thetan's own experiences, whether in current or past lives. Scientology holds that the thetan is basically good, but it has lost its spiritual identity and operates at a small fraction of its natural ability (COSI 1998b:1920). The entrapment by MEST happened trillions of years ago when thetans became bored, and in the process emanated their own mental universe to play in, to amuse themselves. They became progressively more absorbed in the games they were playing. This caused further limitations of their abilities and also imposed limitations on other thetans, which in turn became more dependent upon the material universes that they had created. They became so enmeshed in their creations that they forgot their origins and true status, and lost the ability to mobilise their spiritual capacities. This resulted in the belief that they were no more than the bodies they inhabited (Hubbard 1961:576; Wallis 1977:104). Instead of controlling MEST, they became entrapped by it and in the process lost their spiritual ability. This caused man to act irrationally and with evil intent, even though man is inherently good and highly ethical (COSI 1998b:21). "It is man's experiences that have led him to commit evil deeds, not his nature" (COSI 1998b:4).

The creed of the Church of Scientology was written by $L$ Ron Hubbard in 1954, shortly after the church had been founded. The creed makes it clear that the condition of the human being is viewed as follows (COSI 1998a:619):

- Humans are basically good.

- $\quad$ They seek to survive.

- $\quad$ Their survival depends upon themselves, their fellows and their attainment of brotherhood with the universe.

- $\quad$ The spirit can be saved and the spirit alone may save or heal the body. 
The influence of Hinduism on Scientology is evident. Most adherents of Hinduism believe that they are in their true selves (atman) extended from and one with Brahman - the ultimate reality (Halverson 1996:89). In Scientology the eighth dynamic is the urge towards existence and infinite survival (COSI 1998:22). When the eighth dynamic is reached, the thetan becomes one with infinity that embraces the "Allness of All" (COSI 1998b:24). This is similar to Hinduism's merge into oneness when the individual disappears. It speaks of "God-realisation".

In Hinduism the Creator (God) is viewed as impersonal. The same is true of Scientology. It does not ascribe anthropomorphic qualities to the Supreme Being and it does not embrace an exact description of the character and nature of God the Supreme Being. This is confirmed by the notion that the character and nature of God is a matter of personal experience. The Hindu notion of the ever-revolving wheel of life, death and rebirth (reincarnation or Samsara) is also found in Scientology. According to Scientology man is believed to have more than one life. The lives that have already come to an end are known as "past lives", but the concept of past lives differs from the Hindu concept of reincarnation. In the modern era reincarnation means "to be born again in different life forms". A person's karma determines the kind of body the person will return to - whether human, animal or insect (Halverson 1996:90). The original meaning of reincarnation was "to be born again into the flesh or into another body". Although Scientology's definition corresponds with the original definition of reincarnation, it refers to it as "past lives" (COSI 1998a:531). At death, the thetan and the body separate. The thetan "picks up" another body that has been produced according to a certain blue print that has been in existence since the earliest times (Hubbard 1996:57).

Although Scientology does not view "past lives" as a dogma (COSI 1998a:531) the whole concept of "fall from perfection" or "entrapment by MEST" is the result of a thetan's own experiences in its current life or in past lives (COSI 1998b:21). This is a very important point in auditing. A man may lose sight of his true nature entirely over the course of many lifetimes, and as the result fall from spirituality. The goal of auditing is to reverse this decline, to rid the person of the accumulation of engrams over different lifetimes: "It enables the being to cast off the spiritual chains that grow heavier from lifetime to lifetime - the accumulation of his pains and misfortunes, confusions and his own moral transgressions" (COSI 1998b:33-34). The ultimate goal of Scientology is to reach "complete spiritual ability, freedom, independence and serenity, to be freed from the endless cycle of birth and death" (COSI 1998b:37). The aforementioned references to "reincarnation" confirm it to be one of the foundations of Scientologists' teaching on salvation. 
In Hinduism it is believed that a person's karma in a previous life will determine the life form to which the person will return. Scientology believes that "what we create in our societies during this life time affects us during our next life time" (Hubbard 1996:55). This belief also reflects Hinduism's liberation of illusion and ignorance. Scientology's solution lies in the removal of "engrams" situated in the reactive mind of a person through auditing. This practise will not only free the person from engrams, but will also enhance the person's spirituality.

Siddhartha Gautama (later known as Buddha), the son of a wealthy Hindu rajah, spent years in search of fundamental truths and declared that man could find a middle course between the extremes of sensual indulgence and drastic asceticism. He proclaimed that man is a spiritual being who can achieve an entirely new state of awareness. He termed this state bodhi (COSI 1992:17). A person could only test the truth or determine the real truth through personal experience. True disciples of Buddha must test the truth for themselves (COS 1973:13). This idea has also been incorporated in the doctrines of Scientology. Every person has to determine what the truth is. In Hubbard's own words: "A philosophy can only be a road to knowledge. It cannot be crammed down one's throat. If one has a route, he can then find what is true for him. And that is Scientology" (COSI 1998a:611).

Buddha's immediate goal was to eliminate the causes of suffering. His ultimate goal, however, was to become liberated from the cycle of death and rebirth (samsara). Liberation can be obtained when a person ceases to crave and thereby eliminates his or her attachment to and beliefs in the existence of the illusory self. If a person eliminates these attachments successfully, the effects of karma will have nothing to attach themselves to and the person is released from the realm of illusion. At that moment of enlightenment a person achieves the state of nirvana, the ultimate goal of Buddhism and Buddhism's equivalent of salvation (Halverson 1996:59). In Scientology the same idea of the existence of the illusory self is expressed. In addition it is taught that knowledge of truth can only be obtained through Scientology (COSI 1998a:531). The Buddhist belief that there are many paths to God also feature in Scientology: "There are probably many types of redemption. That of Christ was to heaven" (COSI 1992:545).

Other explanations of life and the mind are comparable with Shinto beliefs. One example is the belief that a person's experiences are recorded as

\footnotetext{
${ }^{4}$ An engram is a particular type of mental image, a complete recording, down to the last accurate detail, of every perception present in a moment of partial or full "unconsciousness". These pictures are stored in the reactive mind (COSI 1998a:686). Engrams also include the recording of painful experiences that affect the person without his/her conscious knowledge (COSI 1998:66).
} 
a film-like memory - mental image pictures. (Sawada 1996:5). Desire can be eliminated and the state of nirvana reached by following the Eightfold Path in Buddhism, and likewise many higher states of existence are available to man and attainable through Scientology. Life is improved on a gradient. The step by step trajectory towards liberation from ignorance in Scientology is called the "Eight Dynamics". The Buddhist path moves through the following stages: right understanding; dedication; communication; conduct; way of life; effort; awareness; and meditation. A person who has gone through all these stages achieve a state of joyful liberation and become separate from the world. Scientology also describes a path or bridge that marks out progress towards liberation. However, the path of Scientology has more in common with the Taoist approach to achieve spiritual harmony in the midst of the world than with the Buddhist path designed for a monastic life. The comparison is evident: In Taoism liberation is viewed as a state of balance in which a human being is in harmony with all the conditions of existence. Scientology is directed at attaining a similar harmony (Chidester s a:5; COSI 1998:98).

From an ecumenical point of view Scientology's doctrine of death and rebirth undermines the authority of the Christian church concerning salvation and everlasting life through the grace of Christ. The threat of eternal damnation also loses its sting against the backdrop of this doctrine (Hubbard 1996:55). COSl's perception of "man" shows strong resemblances to eastern religions such as Hinduism, Taoism and Buddhism, and no resemblance to Christianity.

\subsection{Salvation}

The concept of salvation in Scientology differs from the Christian concept of salvation. Scientologists' understanding of salvation is based on the belief that the immortal thetan is intrinsically good, but has lost its true spiritual identity and therefore operates at a small fraction of its natural ability (COSI 1998a:562). This condition of the thetan causes man to be unhappy and to act irrationally and with evil intent. This points to the entrapment of the thetan. Scientologists concept of salvation lies in the belief that man finds himself in a cycle of eternal survival comparable to reincarnation, which they call "past lives".

According to the teachings of Scientology, the experiences of the thetan are recorded on a "time track", which consists of "mental image pictures" of all perceptions of the past. These mental images are similar to a movie. The time track records experiences of the thetan's current life as well as past lives. These recorded experiences include moments of pleasure but also moments of pain or trauma that are hidden from conscious view. These 
painful experiences are responsible for the entrapment of the thetan and are called "engrams". When the thetan is reminded of such traumatic past incidents it can reactivate the relevant portions of the time track and reactivate and exert an involuntary influence on the thetan and the body. The result of this reactivation is pain, negative emotions or irrational behaviour, which in turn prevent the person from achieving his or her full potential (COSI 1998a:562).

Through Scientology a person can confront his or her evil actions, erase the ignorance and aberration that surround him or her, and come to know and experience truth again (COSI 1998a:531). Scientology prescribes a path that can be followed to assist the thetan in progressing through higher and higher spiritual levels. This may enable the thetan to return to his or her native state and achieve complete spiritual freedom. The primary road to spiritual freedom, however, is "auditing" (COSI 1998a:562).

The term "auditing" comes from the Latin word audire, which means "to hear or listen". Auditing refers to a unique form of personal counselling with the aim of assisting an individual to look back on his or her own life and to improve his or her ability to confront what and where he or she is. Auditing is done by an auditor, who is normally a minister or minister-in-training of the Church of Scientology (COSI 1998a:685). Auditing is viewed as a workable technology to improve the functions of the mind and to rehabilitate the potential of the spirit (COSI 1998a:81). Auditing is also known as processing, which refers to "the application of Scientology processes and procedures to someone, by a trained Auditor" (Vosper 1971:75).

The goals of auditing are: (1) to help the individual rid himself or herself from any spiritual disabilities (engrams) and to become a clear, and (2) to increase individual abilities in order to achieve his or her full potential by moving up through the levels of "Operating Thetan" (COSI 1998a:82).

The auditing process consist of exact sets of questions asked or directions given by the auditor in order to help a person to identify the areas of distress in his or her life and to find out more about himself or herself. A person who has just started the auditing process is called a pre-clear. The aim of auditing is to bring the person to the level of a clear - one whose reactive mind has been cleared of all negative experiences that hinder the person to obtain his or her full potential (COSI 1998a:82). A clear also enjoys improved mental and physical health, as well as enhanced powers, such as a higher IQ and better memory (Aldridge 2000:14).

During the auditing process a religious artefact known as the Electropsychometer (E-Meter) is also utilised. The E-Meter functions on the principle that a person holds the meter's electrodes, one in each hand, while a very tiny 
flow of electrical energy (about 1.5 volts) passes through the wires of the meter, through the person's body and back into the E-Meter. The painful pictures and upsetting experiences in the reactive mind can have a harmful effect on the person because it carries an energy or force called a charge. When the person reflects on these negative experiences during the auditing process, the charge of the harmful experiences register on the dial of the Emeter. This auditing process is repeated until a person has rid himself or herself from these irrational fears and psychomatic disabilities (engrams) until the reactive mind has been cleared. The person in question then becomes a clear (COSI 1998a:85). Much of an auditor's success depends on his or her ability to interpret the E-Meter accurately. If the pre-clear has thoroughly inspected the subject, that is, has erased all charge, the meter needle will "float" - it will not show any reading (Vosper 1971:83).

The state of a clear compares to "satori" in Buddhism. Satori refers to the state where all thought has ceased as the result of Zen meditation. When an auditor guides a person to meditates on his or her experiences (e g childhood or past lives), the person reflects on the way he or she is now. Auditing, like meditation, aims to determine one's current state in life through reflection on the past (Sawad 1996:7; Halverson 1996:68). This reflection on the past aims at discovering, understanding and eliminating the hindrances of the past. In this way the human being, the thetan, develops away from the emotional hindrances and reactive mind, and reaches higher levels of insight and freedom (Berglie 1996:4-5).

Scientology calls the path to enlightenment the Bridge to Total Freedom. On this path, person can become progressively more spiritually aware through training and auditing (COSI 1998a:98). The religious practices of training and auditing are the sine qua non of Scientology. They light the path to higher states of spiritual awareness and ability, and to spiritual salvation (COSI 1998b:31). Great enlightenment and a spiritual beingness comparable to "Chin-Kon-Ki-Shin" (the great secret of Shinto, which means "to appease the spirit of man so that he can return to a God-like state") are achieved (Sawada 1996:6). Training in Scientology has a broad scope and can be divided into numerous courses, ranging from lower level courses that teach basic principles to upper level courses that cover the full philosophical and technical contents of Dianetics and Scientology. In this sense, training offers just as much spiritual insight as auditing. Spiritual awareness and empowerment can only be achieved in full by travelling up both sides of the Bridge to Total Freedom (Kliever 1994:10).

In Christianity human beings are viewed as damaged and sinful by nature from the beginning. According to Christian thought, people cannot rid 
themselves of sin through human effort - only God can do that. Scientology holds a different view. It believes that salvation is obtained through confession and an understanding of one's self (Sivertsev 1995:12). In Scientology, salvation moves a thetan from a state of personal ignorance and bondage (entrapment in MEST) to enlightenment and freedom from MEST. Salvation is a process - one is saved progressively from engrams as one's knowledge (offered by Scientology) and spiritual awareness increases, and one's original state and native powers are restored. A person has to travel a spiritual road from the state of a pre-clear to the highest level ("Operating Thetan" - one who can handle things without having to use a body or physical means). When a person has reached the highest spiritual level, he or she can handle things that exist without physical support and assistance. A person on one of the 15 operating levels has achieved the ultimate realisation of his or her own nature and his or her relationship to life and the dynamics (COSI 1998a:167).

What then is the salvation that Scientology offers? It is not salvation to heaven, but full spiritual awareness and responsibility that ensure spiritual freedom, in other words spiritual salvation. The salvation is brought about by the principles of Scientology that assist a person in finding his or her own answers to life's problems. This is achieved by examining his or her own existence and improving his or her ability to face what and where he or she is (COSI 1998b:34).

\section{COMPARISON OF TWO CONCEPTS OF SALVATION: CHRISTIANITY AND SCIENTOLOGY}

The concept of reincarnation or the belief in "past lives" is the essential foundation of Scientology's understanding of and teachings on salvation. The Christian belief is that man needs to be saved from eternal damnation and death. Christianity views death as the passageway to eternal life. Those that are not saved will experience eternal damnation. Scientology believes that a human being returns after death in another body of flesh - there is therefore no fear of eternal damnation. There is also no need to obtain salvation to heaven, because the cycle of birth and rebirth is a continuous cycle of existence. Christ as the only saviour of mankind is replaced by human efforts. Salvation is achieved through auditing and training, which assist a person in regaining an understanding of and responsibility for his relationship with life and the Supreme Being.

In Scientology there is no definite personal relationship between God and the human being as entities. Christianity emphasises the personal relationship between the divine and the human. In Scientology the perception is that the ultimate aim of salvation is to become one with the Supreme Being: 
"In this spiritual state (that of Operating Thetan) it is possible for the thetan to possess complete spiritual ability, freedom, independence and serenity, to be freed from the endless cycle of birth and death, and to have full awareness and ability independent of the body" (COSI 1998b:37).

According to Scientology, salvation is based on the view that mankind is not corrupt, already basically and naturally good. Mankind only needs enlightenment. Lost potential only needs to be regained and restored through Scientology. The salvation offered by Scientology essentially means that a human being can be saved through his or her own efforts and the guidance of Scientology. The Christian view is that man can only be saved through the intervention of God through Christ.

\section{CONCLUSION}

The different beliefs concerning "salvation" in Christianity and Scientology have one thing in common: both religions aim to free man's soul from bondage. Scientology aims to free the soul from MEST entrapment through human practices, and to restore the thetan to its native power and its ability to control MEST or to be at cause (to be able to determine the course of events). The other, Christianity, is to bring people to a place where they realise that they are sinful and that salvation can only be obtained through the acceptance of Christ as Saviour. The first can be termed salvation through own efforts and the last salvation through divine intervention.

\section{Works consulted}

Aldrige, A 2000. Religion in the contemporary world. Cambridge: Polity.

Ankerberg, J \& Weldon, J 1996. Encyclopedia of New Age beliefs. Portland, OR: Harvest House.

Anon 2000. Scientology recognised religion. Citizen, 4 April 2000.

Anon 2005. Religion: Wikipedia, The Free Encyclopedia. Available http://en.wikipedia.org/wiki/Religion

Berglie, $\mathrm{P}$ 1996. Scientology: A comparison with religions of the East and West. Los Angeles, CA: Freedom. (COSI.)

Berglie, P 1973. The Church of Scientology: The background and ceremonies of the Church of Scientology of California, World Wide. London: Krisson.

Chidester, D s a. Scientology: A religion in South Africa. Los Angeles, CA: Freedom. (COSI.)

Chidester, D 1994. A description of the Scientology religion. Los Angeles, CA: Bridge. (COSI.)

Chidester, D 1998a. What is Scientology? Los Angeles, CA: Bridge. (COSI.)

Chidester, D 1998b. Theology and practice of a contemporary religion. Los Angeles, CA: Bridge. (COSI.) 
Chidester, D 2004. What is Scientology? Available http://www.Scientology.org (COSI.)

Chidester, D 1992. What is Scientology? California, CA: Bridge.

Halverson, D C (ed) 1996. The compact guide to world religions. Minneapolis, MN: Bethany House.

Hubbard, L R 1961. A history of man. Sussex: L Ron Hubbard Communications Office.

Hubbard, L R 1968. The creation of human ability. Los Angeles, CA: The publication organization worldwide.

Hubbard, L R 1996. The rediscovery of the human soul. Los Angeles, CA: L Ron Hubbard Library.

Kliever, L D 1994. Scientology: A worshipping community. Los Angeles, CA: Freedom.

Khumalo, F 2000. Sciëntologie-kerk se eerste swart leraar. Rapport, 27 Augustus 2000.

Louw, J P \& Nida, E A 1993. Greek-English Lexicon of the New Testament based on semantic domains, Vol 1. Cape Town: Bible Society of South Africa.

Oosthuizen, G C 1977. Religious philosophy, religion and church. Los Angeles, CA: Freedom.

Sawada, F 1996. The relationship between Scientology and other religions. Los Angeles, CA: Freedom.

Sivertsev, M A 1995. Scientology: A way of spiritual self-identification. Los Angeles, CA: Freedom.

Vosper, C 1971. The mind benders. London: Neville Spearman.

Wallis, R 1977. The road to total freedom: A sociological analysis of scientology. New York: Columbia University Press. 